\title{
A organização territorial em um espaço de fronteira com o império espanhol e seu vocabulário. Notas de pesquisa ${ }^{1}$
}

\author{
Helen Osório
}

Universidade Federal do Rio Grande do Sul, Brasil

Resumo. Aborda-se as dinâmicas espaciais e administrativas que produziram um determinado ordenamento territorial em uma área de fronteira que, a partir de 1763, constituiu a capitania do Rio Grande de São Pedro. Indaga-se sobre os processos econômicos e sociais que levaram à criação das freguesias (paróquias) e verifica-se que elas foram a circunscrição essencial que conformou o espaço: censos de população, de produção e a organização de milícias tinham por referência as freguesias. Analisa-se também o vocabulário que, na América portuguesa, definia as diferentes unidades de povoamento e sua evolução. Finalmente, ao se analisar as primeiras décadas de existência do império do Brasil, verificou-se a continuidade da centralidade das freguesias no ordenamento da administração e da política.

Palavras-chave: Organização territorial - freguesias - fronteira-América portuguesa

\begin{abstract}
The article discusses the spatial and administrative dynamics that produced a particular land arrangement on a border area which, since 1763, was the captaincy of Río Grande de San Pedro. Economic and social processes that led to the creation of parishes (freguesias) were investigated and it is verified they were the essential constituency which conformed the space: population and production censuses, and organization of militias, used parishes as reference. The text also analyzes the vocabulary which defined the different units of settlement in Portuguese

\footnotetext{
${ }^{1}$ A presente investigação conta com financiamento do CNPq, através de bolsa de produtividade e do
} Edital 14/2013.
\end{abstract}


America and their evolution. Finally, on the analysis of the first decades of the empire of Brazil, the work shows the continuity of the centrality of parishes in the administration and politics systems.

Keywords: Territorial organization - parishes - border - Portuguese America

O artigo aborda a constituição do espaço colonial português na América meridional, profundamente marcado pelos interesses geoestratégicos da coroa lusa na região e os confrontos com o império espanhol, durante o século XVIII. Do primeiro assentamento, um presídio, até a ereção das freguesias (paróquias), analisam-se as relações recíprocas entre a estruturação econômica (exploração gado selvagem e posterior estabelecimento de estâncias) e os interesses e a capacidade administrativa da coroa e seus agentes locais, na conformação do espaço. Inicialmente realizaremos uma breve análise do léxico utilizado na capitania para designar os diferentes povoados e seu estatuto administrativo, para em seguida determo-nos nas freguesias. Elas moldaram a vida administrativa da capitania e foram um referente espacial muito importante. Indaga-se no trabalho, ainda de forma preliminar e com um conjunto restrito de fontes, sobre os processos fundacionais das povoações e suas motivações: atividades produtivas junto aos rios ou no caminho das tropas de animais rumo a São Paulo; funções militares (quartéis e armazéns reais), e objetivos defensivos.

Depois, relaciona-se a constituição da escassa malha administrativa com o processo de apropriação de terras através do instituto das sesmarias, para se ter uma visão de conjunto da evolução da ocupação territorial. Por fim, inquire-se sobre a permanência, ou não, da circunscrição "freguesia" como angular para o ordenamento territorial e político do estado brasileiro que se construía.

\section{Uma aproximação ao vocabulário da ocupação e ordenamento territorial}

Cinco são os termos que surgem na documentação administrativa e nas atas da Câmara da Vila de Rio Grande para designar os aglomerados humanos e 
circunscrições existentes na capitania: arraial, aldeia, freguesia, vila e distrito.

Em Portugal, arraial significava "o alojamento de um exército na campanha"2. Na América adquiriu outro significado. Nas Minas Gerais, como analisou Cláudia Damasceno Fonseca, designou os povoados criados ao redor da atividade mineradora. Neste sentido, foi utilizado também em Mato Grosso e Goiás. ${ }^{3}$ Mais ao sul, essa denominação teve escasso uso, como observou o botânico francês Auguste de Saint-Hilaire no início do século XIX:

\begin{abstract}
“Deve-se notar que na província de Santa Catarina não se usa o termo arraial para designar seus povoados, como em Minas, e sim o termo freguesia, paróquia. A palavra arraial, no sentido estrito, significava um lugar de acampamento e, de fato, os primeiros mineradores só faziam acampar; porém, a grande quantidade de ouro que encontraram em certas regiões fez com que eles ali se fixassem, e a palavra arraial foi assim, pouco a pouco, perdendo sua significação primitiva. Nada semelhante ocorreu em Santa Catarina, onde não havia minas a explorar."4
\end{abstract}

No Rio Grande, apenas uma povoação recebeu, desde seu princípio, essa denominação: o "arraial de Viamão". A segunda mais antiga freguesia da capitania (1747), com sua primeira população oriunda de Laguna e São Paulo, foi assim denominada desde seus princípios até 1778, quando deixa de ser utilizada ${ }^{5}$. No caso, parece que o uso da palavra aponta para a provisoriedade e os momentos iniciais de ocupação do território.

Aldeia, que em Portugal designava "povoação pequena, de poucos vizinhos, que não tem jurisdicçáo própria, mas depende da Villa, ou Cidade vizinha", na América designava exclusivamente as povoacões compostas por índios. Esse sentido foi dicionarizado já em 1789, por Moraes: "no Brasil, aldeias de índios, são as povoações dos domesticados, e que descem dos Sertões"6. Efetivamente, o termo é

\footnotetext{
2 BLUTEAU, Rafael, Vocabulario Portuguez e latino,Coimbra, Collegio das Artes da Companhia de J esus, 1712-1721, vol. I.

3 FONSECA, Cláudia Damasceno, Arraiais e vilas d'El Rei. Espaço e poder nas Minas setecentistas, Belo Horizonte, Editora UFMG, 2011, p. 64.

${ }^{4}$ SAINT-HILAIRE, Auguste de, Voyage dans les provinces de Saint-Paul et de Sainte-Catherine, t. II, p. 243. apud FONSECA, ob.cit.

5 Mesmo sendo sede da Câmara de Vereadores de Rio Grande entre 1763 e 1772, a localidade continuava sendo assim nomeada por várias autoridades, inclusive as camarárias.

${ }^{6}$ Moraes Silva, por ser originário do Brasil, era muito atento às novas acepções americanas das palavras e frequentemente as indica em seu dicionário. MORAES SILVA, Antonio, Diccionario da
} 
utilizado para designar a "a aldeia dos índios Tape" fundada ao norte do porto de Rio Grande e que dará origem à freguesia de Estreito, e à "aldeia de Nossa Senhora dos Anjos", formada por índios guarani oriundas das missões jesuíticas, como se verá adiante.

O termo freguesia foi o mais utilizado em todas as capitanias do Brasil para referir as paróquias, a circunscrição básica da administração eclesiástica. Raramente encontra-se a designação paróquia na documentação que não seja eclesiástica. Enquanto em Minas Gerais uma freguesia "compreendia geralmente diversas povoações - a que acolhia igreja matriz e outras que possuíam apenas uma capela filial"7, no Rio Grande do século XVIII, a escassez de capelas filiais fez com que o termo freguesia se tornasse, na prática, sinônimo de povoação e a referência mais frequente aos aglomerados urbanos.

Enquanto em Portugal a palavra vila teve um uso mais alargado, existindo topônimos que incluem essa denominação e não possuíam um concelho ou câmara, na América "as localidades recebiam o título de vila ao mesmo tempo em que adquiriam o direito de se autogerirem"s, quer dizer, possuir uma câmara com seu território próprio de jurisdição (termo) e rendas exclusivas. Na capitania do Rio Grande houve apenas uma vila, a de Rio Grande, com uma trajetória itinerante, pois sua câmara teve sua sede em diferentes lugares ${ }^{9}$. Dada essa particularidade, a expressão vila foi utilizada para mais de uma localidade: Rio Grande e Porto Alegre. Outra particularidade foi que o termo, a jurisdição dessa Câmara abarcava a totalidade da capitania.

Por fim, a palavra distrito teve um uso amplo e impreciso, da mesma forma que ocorria em Portugal ("o espaço de lugar a que se estende qualquer jurisdição") 10, sendo utilizada para designar vários tipos de divisões territoriais. No entanto, pode-se assinalar que um de seus usos mais frequentes, tanto em Minas Gerais ${ }^{11}$ quanto no

lingua portugueza composto pelo padre D. Rafael Bluteau, reformado, e accrescentado por Antonio de Moraes Silva natural do Rio de J aneiro, Lisboa, Na Officina de Simão Thaddeo Ferreira, 1789.

${ }^{7}$ FONSECA, ob. cit., p. 86.

${ }^{8}$ Idem, p. 29.

9COMISSOLI, Adriano, Os "homens bons" e a Câmara Municipal de Porto Alegre (1767-1808),Porto Alegre, Gráfica da UFRGS, 2008.

${ }^{10}$ BLUTEAU, ob. cit.

${ }^{11}$ FONSECA, ob. cit., p. 80. 
Rio Grande do Sul foi para designar as circunscrições das tropas de ordenanças ou das tropas auxiliares ${ }^{12}$.

\section{Expansão portuguesa, conformação do território e criação de freguesias}

Na segunda metade do século XVII, a partir de São Paulo, avança-se para o sul. Em 1648 surge Paranaguá, em 1658 São Francisco do Sul, em 1668 Curitiba, em 1675 ocupa-se a ilha de Santa Catarina e no ano seguinte, a zona de Laguna, que permanecerá como a última povoação portuguesa até a fundação de Rio Grande em 1737.

O reconhecimento do território entre a Colônia de Sacramento e a Laguna fora feito em 1703 por Domingos Filgueira13; em 1723 houve uma tentativa frustrada de instalar-se no sítio de Montevideo e em 1736, em correspondência a Gomes Freire de Andrade, governador e capitão-general do Rio de Janeiro e Minas Gerais, o rei D. J oão V ordena ações “...para facilitar aos navios portugueses do comércio a livre navegação do dito rio ...", e para tentar tomar Montevideo e fundar o Rio Grande ${ }^{14}$.

Em fevereiro de 1737 foi fundado o presídio J esus-Maria-J osé em Rio Grande, após nova tentativa frustrada de tomar Montevideo e estabelecer-se em Maldonado. A palavra presídio designa uma praça de guerra, um forte. Repete-se a organização espacial da Colônia de Sacramento e mesmo de Montevideo: um porto, e um pequeno núcleo fortificado. A fortaleza é administrada por um comandante, através da instituição da Comandância Militar do Rio Grande de São Pedro, subordinada diretamente à Capitania do Rio de Janeiro. Sua jurisdição abrangia as terras à margem direita do canal da barra para a parte do sul, até encontrarem as de Espanha (Chuí e Cerro de São Miguel) ${ }^{15}$. A descontinuidade da organização administrativa

\footnotetext{
12 Frequente na documentação é a expressão "capitão do regimento de cavalaria de milicias do distrito de...".

13 "...gastamos da Colônia até Castilhos 24 dias; de Castilhos até o Rio Grande 16 dias. Estes fazem 70. São andantes, que os que faltam para quatro meses foram de falhas"."Roteiro por onde se hao de governar da Colônia até chegar a povoados do Rio de J aneiro, ou capitania de Santos", Biblioteca da Ajuda, Lisboa, ms. 51-V-37.

14 Carta de Lisboa, 23 março 1738, apud FORTES, J oão Borges, Os casais açorianos, Porto Alegre, Martins Livreiro-editor, segunda edição, 1978, p.17.

${ }^{15}$ CÉSAR, Guilhermino, História do Rio Grande do Sul. Período colonial, Porto Alegre, Globo, 1970, p. 113.
} 
(com os campos de Viamão dependentes de São Paulo) reflete a descontinuidade espacial e revela o caráter estratégico que a Coroa dava ao estabelecimento, atribuindo-lhe um governo militar específico.

As motivações estratégicas da coroa portuguesa em sua expansão rumo ao Rio da Prata incidiram diretamente no processo de constituição das freguesias, como indica o ordenamento proposto no quadro 1. Esta primeira aproximação a uma tipologia das origens das freguesias está inspirada na realizada por Mariana Canedo para os povoados rurais de Buenos Aires. ${ }^{16}$

O presídio com sua guarnição militar, fundado em 1737, adquire o estatuto de freguesia no ano seguinte e será o único porto marítimo do território meridional. Em 1751 tornar-se-á a única vila da futura capitania. Em 1763 será tomada pelos espanhóis, até 1776.

Dois anos após a fundação do presídio foi estabelecida a Guarda de Viamão (1739), 60 léguas ao norte17, para controlar o fluxo das tropas de muares e cavalares que se dirigiam a São Paulo e Minas Gerais. Aí cobrava-se um imposto por cabeça de animal. J unto a esta guarda em 1752 a coroa criou o Registro de Viamão, para fortalecer o controle, e passou a arrematar, sob a forma de um contrato trianual, a cobrança dos direitos sobre as tropas de animais ${ }^{18}$. A partir da guarda, do registro, das lojas que os contratadores mantinham no local e do movimento dos tropeiros, fixou-se uma povoação que originou a freguesia de Santo Antônio da Patrulha.

${ }^{16}$ CANEDO, Mariana "Derechos de propiedad, prácticas sociales e intervenciones políticas. Los pueblos rurales en Buenos Aires, 1750-1860", Congreso Internacional de historia agraria. Congreso internacional de la SEHA; Badajoz, 2013.

17 A légua portuguesa equivale a 6.600 metros. Distância descrita em: BETTAMIO, Sebastião Francisco, "Notícia particular do Continente do Rio Grande", [1779].

18 OSÓRIO, Helen, O império português ao sul da América: estancieiros, lavradores e comerciantes, Porto Alegre, Editora da UFRGS, 2007, p. 229. 


\section{Quadro 1. Origem das freguesias instituidas durante o século XVIII}

\begin{tabular}{|l|l|l|l|}
\hline \multicolumn{1}{|c|}{ Origem } & Ano & \multicolumn{1}{|c|}{ Nome } & $\begin{array}{c}\text { Ano fundação } \\
\text { freguesia }\end{array}$ \\
\hline Presídio & 1737 & Rio Grande & 1738 \\
\hline $\begin{array}{l}\text { Guarda e } \\
\text { registro }\end{array}$ & 1739 & Santo Antônio da Patrullha & 1763 \\
\hline Fortaleza & 1752 & & 1762 \\
\hline Armazém Real & 1751 & Rio Pardo & 1773 \\
\hline $\begin{array}{l}\text { Aldeamentos } \\
\text { indígenas }\end{array}$ & 1752 & Santo Amaro & 1761 \\
\hline Assentamentos & 1753 & Estreito & 1773 \\
espontâneos: & 1759 & Nossa Senhora dos Anjos & 1747 \\
de gado de criação & $1741^{*}$ & Viamão & 1756 \\
& $1756^{*}$ & Triunfo & 1762 \\
& $1761^{*}$ & Vão Francisco Cima da Serra & 1768 \\
& $1742^{*}$ & Conceição do Arroio & 1773 \\
\hline Iniciativa de & $1760^{*}$ & Caxoeira & 1779 \\
governador; \\
instalação açorianos & & Taquari & 1765 \\
& & Porto Alegre & 1772 \\
& & Lombas & 1773 \\
\hline
\end{tabular}

* Refere-se ao ano de fundação de capela

Fontes: Livros da Provedoria da Fazenda, Arquivo Histórico do Rio Grande do Sul (AHRS); documentação avulsa do Rio Grande do Sul, Arquivo Histórico Ultramarino (AHU) e Rubert, Arlindo, História da Igreja no Rio Grande do Sul - Época Colonial (1626-1822), Porto Alegre, EDIPUCRS, 1994.

Na década de 1750, com a assinatura do Tratado de Madrid e a presença do governador do Rio de J aneiro, Gomes Freire de Andrade, na Colônia de Sacramento e depois em Rio Grande, iniciam-se os preparativos para a demarcação de limites e remoção das aldeias jesuíticas da margem oriental do rio Uruguai. No rumo oeste, a criou de um forte (1751) às margens do rio J acuí, no meio caminho para as Missões, que originou a freguesia de Rio Pardo. Nas margens do mesmo rio, quilômetros antes, estabeleceram-se armazéns reais para apetrechos de guerra (para abastecer os exércitos portugueses na incursão às missões), que estiveram na origem, vinte anos depois,da freguesia de Santo Amaro.

Gomes Freire de Andrade foi responsável, também, por dois aldeamentos indígenas que posteriormente constituíram freguesias como acréscimo de população de origem européia. O primeiro, próximo do porto de Rio Grande, no outro lado do 
canal (Estreito), congregou índios tape em 1753 em uma estância, dando origem a uma aldeia. O segundo, com um contingente indígena importante, por volta de 3.000 índios oriundos das missões jesuíticas em desagregação após a chamada "guerra guaranítica". Esta população ficou inicialmente sediada em Rio Pardo e em1759 foram trasladados às proximidades do rio Guaíba (Aldeia de Nossa Senhora dos Anjos).

Até o final da década de 1760 houve, portanto, seis iniciativas diretas da coroa que acabaram por resultar na criação de povoações constituídas em freguesias.

O projeto português após a entrega dos povos missioneiros pela Espanha era de povoá-los com migrantes açorianos que haviam sido conduzidos inicialmente à Ilha de Santa Catarina. Entre 1752 e 1754, um contingente de aproximadamente 2.300 pessoas foi trasladado ao Rio Grande ${ }^{19}$. Com o fracasso da entrega do território das missões aos lusitanos, os casais açorianos paulatinamente foram situando-se em vários pontos ao longo das margens do rio J acuí ${ }^{20}$, sem a assistência prometida pela coroa (instrumentos agrícolas e concessão de terras). A invasão espanhola de 1763 fez a população debandar rumo ao norte ${ }^{21}$, desorganizou a administração e postergou 0 assentamento dos açorianos. Quatro freguesias foram criadas especificamente para sua fixação, por iniciativa de dois governadores, em 1765 e 1773.

Finalmente, estão as freguesias surgidas espontaneamente, na falta de uma melhor expressão, a partir da exploração do gado selvagem, do estabelecimento de estâncias de criação e do fluxo das tropas de muares e cavalares para a feira de Sorocaba em São Paulo e Minas Gerais. Das seis povoações assim criadas, como era de se esperar, cinco tiveram como antecedente a ereção de uma capela, geralmente na estância de algum rico proprietário. Viamão, São Francisco de Cima da Serra, Vacaria e Conceição do Arroio beneficiaram-se de migrações de paulistas e lagunistas que desde a década de 1720 incursionavam pelo território em busca de animais e situaram-se no eixo dos caminhos que conectavam o extremo sul comas capitanias mais ao norte.

\footnotetext{
${ }^{19}$ Nenhum estudo conseguiu ainda precisar o número de açorianos que migraram ao Rio Grande nesse momento. A estimativa foi feita por Aurélio Porto. Ver: CESAR, G., ob. cit., p.131.

20 Vide "Mapa da Fronteira do Rio Pardo", ao final.

${ }^{21}$ Mas um contingente açoriano estacionado em Rio Grande foi conduzido pelos espanhóis para o território da Banda Oriental e com eles foi fundado um povoado em Maldonado.
} 
A superficial exposição acima realizada acerca das origens das dezesseis freguesias criadas até o final do século XVIII teve como objetivo formar uma visão de conjunto; de forma alguma consideramo-as produtos monocausais. Observando-as em série é possível perceber a importância das iniciativas da coroa em prol de seu projeto expansionista rumo ao sul: seis freguesias estão diretamente vinculadas a esse processo, especialmente as tentativas de demarcação dos limites do Tratado de Madrid, e outras quatro, indiretamente, aquelas que produziram o assentamento dos casais açorianos. Dentre as seis classificadas como "espontâneas", duas, Viamão e Conceição do Arroio, acabaram por ter terras repartidas para açorianos, assim como Estreito,Rio Grande e Santo Amaro, que se iniciaram por ações de representantes da coroa.

\section{Quadro 2.Ano de fundação das freguesias}

\begin{tabular}{|l|l|}
\hline Rio Grande & 1738 \\
\hline Viamão & 1747 \\
\hline Triunfo & 1756 \\
\hline Estreito & 1761 \\
\hline São Francisco de Paula Cima da Serra & 1761 \\
\hline Rio Pardo & 1762 \\
\hline Santo Antônio da Patrulha & 1763 \\
\hline Taquari & 1765 \\
\hline Vacaria & 1768 \\
\hline Porto Alegre & 1772 \\
\hline Lombas & 1772 \\
\hline Conceição do Arroio & 1773 \\
\hline Santo Amaro & 1773 \\
\hline Mostardas & 1773 \\
\hline Nossa Senhora dos Anjos & 1773 \\
\hline Caxoeira & 1779 \\
\hline
\end{tabular}

Fonte: Rubert, ob. cit.

Ao ordenar cronológicamente a fundação de freguesias, observa-se que apenas duas constituiram-se até 1750; a intensificação do povoamento e esse tipo de ordenamento do espaço deu-se nas décadas de 1760 e 1770. Sete freguesias foram erigidas antes da invasão de Rio Grande (1763), e dez após essa perda territorial momentânea. Nesse segundo período, foram distribuídas terras, as denominadas datas de terras aos açorianos e seus descendentes em seis delas, indicando uma 
intenção de ordenamento territorial e social (em princípio os casais açorianos não poderiam abandonar as freguesias em que tinham obtido suas datas e deveriam pedir permissão ao governador para moverem-se).

Apenas uma freguesia foi criada após a expulsão dos espanhóis de Rio Grande (1776). Caxoeira foi a última freguesia fundada (1779) durante o século XVIII. Foi a povoação mais a oeste; sua capela existia desde 1760 no Passo do Fandango, um local estratégico no caminho para as missões.

Das dezesseis freguesias criadas, duas foram extintas ${ }^{22}$ e não constaram mais nos "mapas de população" elaborados a partir de 1780. Restaram quatorze freguesias, sendo que uma delas, Porto Alegre, era capital e sediava a Câmara de Vereadores ${ }^{23 .}$

A campanha de Buenos Aires possuiu uma quantidade semelhante de paróquias. Em 1780 eram quinze, sendo seis anteriores a esta data e nove erigidas nesse ano. Também lá não houve outras criações nas últimas décadas do século XVIII, mas esse tipo de estrutura multiplicou-se até 1820.24 Apenas para contrastar diferentes magnitudes dos processos econômicos e populacionais de áreas centrais do mundo colonial, trazemos os dados de Minas Gerais. Durante o auge da produção de ouro, de finais do século XVII a 1752, foram criadas 123 capelas e destas, quarenta e cinco transformaram-se em freguesias. Até 1730 existiam nove vilas, e outras seis foram criadas entre 1789-1798. ${ }^{25}$ Nenhuma capitania da América portuguesa teve uma malha urbana tão vasta e articulada, não só pela atividade mineratória, mas também pela agricultura e trocas internas.

\section{Catorze freguesias e uma vila}

Expulsos os espanhóis de Rio Grande em 1776, readquiriu-se o único porto marítimo da capitania. O período de paz subsequente favoreceu a expansão da

\footnotetext{
22 Lombas (1772) acabou abandonada pelos casais açorianos devido a má qualidade dos terrenos para a agricultura e São Francisco de Paula de Cima da Serra foi incorporada à freguesia de Vacaria.

23 O estatuto jurídico dúbio de Porto Alegre será abordado adiante.

24 BARRAL, María Elena, "Los párrocos como mediadores en las fronteras del mundo colonial (Buenos Aires rural en el siglo XVIII)", Darío BARRIERA, Justicias y Fronteras. El Río de la Plata (Siglos XVII a XIX), Murcia, Universidad de Murcia, 2009, p. 69.

${ }^{25}$ FONSECA, ob. cit., pp. 106- 130.
} 
pecuária e da agricultura, um intenso movimento de apropriação de novas terras com a expansão territorial rumo ao sul, para a Banda Oriental, e o crescimento demográfico. O primeiro recenseamento realizado em 1780 indicou 17.923 habitantes; o subsequente, em 1798, 31.705 moradores $^{26}$, um crescimento de mais de 70\% da população. Já o rebanho de gado vacum cresceu 320\% de 1780 a 1791 . Os primeiros registros de exportação de couros, charque e trigo para as praças do Rio de J aneiro, Bahia e Pernambuco datam de 178727 .

Toda a documentação produzida, sejam os "mapas" de população, os da produção agrária ou pecuária, estava enquadrada pelas freguesias. Esta divisão eclesiástica era o principal referente espacial e moldou a vida administrativa da capitania. Também o ordenamento militar das tropas auxiliares, de ordenanças e de milícias, e os ramos dos dízimos arrematados por contrato, tinham por unidade as freguesias. A própria auto-declaração de naturalidade dos habitantes, verificável nos processos criminais, remetia às paróquias. Enfim, esta divisão eclesiástica foi aplicada aos mais diversos âmbitos econômicos, sociais (como as confrarias e irmandades) e administrativos. Reproduziu-se aqui o tipo de ordenamento espacial e político que Antonio Manuel Hespanha já analisara para Portugal:

"pela finura de sua malha territorial, pela centralidade das suas funções e pela qualidade do seu equipamento administrativo, a freguesia foi, durante o Antigo Regime, uma circunscrição territorial decisiva no enquadramento político do espaço". ${ }^{28}$

Já Damasceno, ao analisar o caso de Minas Gerais, destaca diferenças de escala geográfica. Enquando na Europa “a divisão do território em paróquias se fez na longa duração", produzindo uma malha extremamente fina, no Novo Mundo, nas Minas, a rede paroquial se constituiu em poucas décadas e era "bastante distendida". Enquanto em Portugal havia 3.987 freguesias em 1745, nas Minas na mesma época eram em torno de cinquenta, cada uma controlando um vasto território. A autora

\footnotetext{
26 Mapa geográfico do Rio Grande de São Pedro suas freguesias e moradores de ambos os sexos, com declaração das diferentes condições e idades em que se acham em 7 de outubro de 1780. Biblioteca Nacional, Río de Janeiro (doravante BN) I-5-4-9, $2^{\circ}$ volume, e Mapa ou numerário de todos os habitantes da capitania do Rio Grande de São Pedro do Sul, o qual expressa as suas condições, estados e sexos divididos pelo número das Freguesias atuais da mesma capitania no ano de 1798. Arquivo Histórico Ultramarino (Lisboa), Fundo Rio Grande do Sul (doravante AHU-RS), Cx.9, doc.44.

${ }^{27}$ Ainda, a população escrava cresceu a um ritmo mais acelerado que a população livre, a uma taxa 4,1\% anual. Osório, ob. cit., p. 70.

28 HESPANHA, A. M., SILVA, Ana C. Nogueira da, “O quadro espacial”, J. MATTOSO (dir.), História de Portugal. O Antigo Regime (1620-1807), Lisboa,Editorial Estampa, 1993, p. 43.
} 
aponta a grande extensão territorial e a indefinição inicial dos limites como características tanto das paróquias quanto da circunscrição civil dos concelhos (vilas) ${ }^{29}$.

Certamente esta foi uma característica das quatorze freguesias e da vila de Rio Grande. A capitania possuiu apenas uma vila com sua Câmara de Vereadores até 1811. Estabelecida na freguesia de Rio Grande, em 1751, tinha jurisdição que se estendia até Laguna (em Santa Catarina), abarcando todo o extremo sul português. Com a invasão espanhola de 1763 a população e a câmara deslocaram-se primeiro para o arraial de Viamão, onde funcionou até 1773. Neste ano o governador ordenou que ela se estabelecesse na recém fundada freguesia de Porto Alegre, criando um conflito com os camaristas. A câmara, que continuou a ser denominada "da vila de Rio Grande", ficou sediada em Porto Alegre, que não tinha o estatuto de vila... Uma anomalia institucional advinda da situação fronteiriça desse espaço ${ }^{30}$.

29 FONSECA, ob., cit., p.86.

30 COMISSOLI, ob. cit. 


\title{
Figura 1- Localização das freguesias criadas até 1822
}

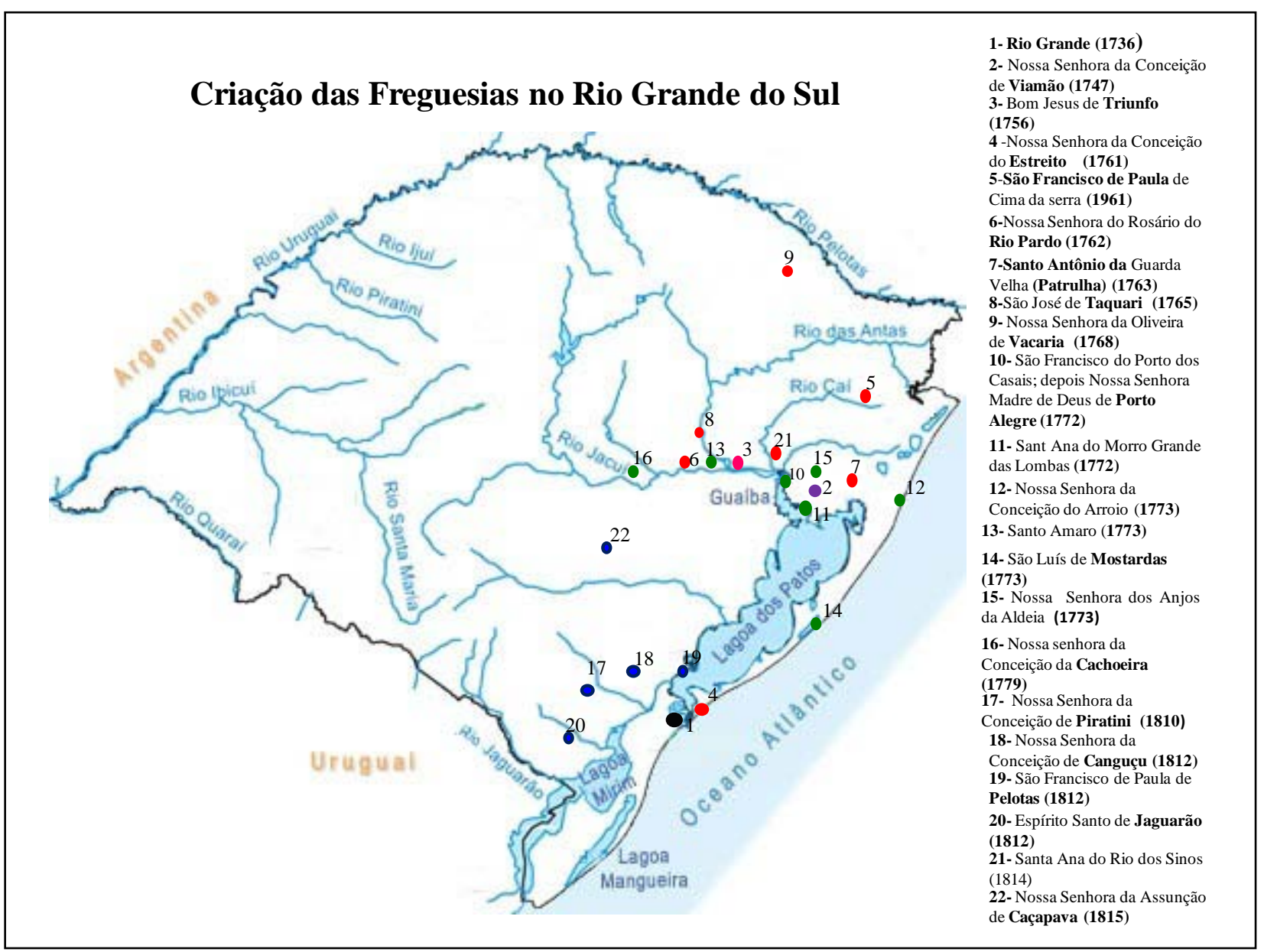

Elaboração da autora. Sinais em preto: freguesias criadas na década de 1730, lilás: 1740, vermelho: 1750, vermelho diferente: 1760, verde: 1770, azul: 1810 .

Em uma petição da Câmara de 1796, os vereadores solicitavam um juiz de fora (letrado), para administrar a justiça. Nela, eles historiavam a trajetória itinerante da Câmara:

\begin{abstract}
"no ano de 1777 foi restaurada aquela invadida Vila; porém sempre ficou esta mesma povoação de Porto Alegre servindo de residência dos Governadores, Provedoria, e Câmara por se achar situada no centro deste grande Continente, e a terem os Vice Reis destinado para capital dele; cujo continente há de ter de extensão de uma a outra Fronteira perto de duzentas léguas, em que se acham erigidas quatorze Freguesias opulentas as quais de necessidade se devem criar Vilas, por ser impossível que dois juizes Ordinários, e esta Câmara possam administrar a tão grandes longitudes; e por esta causa ficam impunidos os Crimes dos malfeitores..."31
\end{abstract}

${ }^{31}$ AHU, RG, Doc. Avulsos, Cx 6, Doc. 3, 8 J unho 1796. 
Sugeriam, pois, os oficiais, que fossem criadas mais vilas,e rogavam "nos mande um Juiz de Fora para melhor serem administradas as Justiças de Vossa Majestade porquanto os Juizes Ordinários como Leigos, e ignorantes das Leis, não as podem fazer executar". A inexistência de juízes letrados foi uma queixa constante dos sucessivos governadores e da própria câmara.

Os dois juízes ordinários que eram eleitos junto com os três vereadores eram insuficientes para exercer as funções judiciais por todo território. Havia no ordenamento jurídico português a figura do "juiz pedâneo" (que julga de pé) ou "juiz da vintena".

Esta última denominação provém da exigência de que existisse esse oficial em todas as povoações de mais de vinte vizinhos que estivessem situadas em lugares distantes mais de uma légua da sede do respectivo concelho. O território de jurisdição destes juízes eram chamados de "vintenas"32. Suas funções eram restritas à aplicação de multas e às causas cíveis de reduzido valor. O cargo era nomeado pela câmara. Damasceno afirma que em Minas Gerais estes juízes associavam-se ao comandante de milícias para interrogar e prender culpados que eram conduzidos para as prisões das vilas. ${ }^{33}$

Na capitania do Rio Grande as freguesias tiveram seus juízes de vintena nomeados apenas a partir de 1779, oitenta ou oitenta e um ${ }^{34}$. Eis outro exemplo de como a administração civil utilizava-se da circunscrição definida pela freguesia para o exercício de seus poderes jurisdicionais.

\section{Concessão de sesmarias: um indicativo da apropriação de terras}

Inicialmente uma comandância militar, a capitania do Rio Grande foi criada em 1760 como subalterna à capitania geral do Rio de Janeiro, e assim se manteve até1807, quando foi elevada à condição de capitania geral. Na carta de lei de 1807 reconhecia-se a importância econômica, populacional e estratégica que estes territórios estavam adquirindo:

32 FONSECA, ob. cit.

33 Idem, p. 189.

${ }^{34}$ Livros de Atas das sessões da Câmara de Vereadores. Arquivo Histórico de Porto Alegre. 
"atendendo à grande distância em que fica do Rio de J aneiro a Capitania do Rio Grande de São Pedro do Sul e o aumento que tem tido há anos em sua população, cultura e comércios, exigem pela sua importância que possa vigiar de perto sobre os interesses dos seus habitantes e da Minha Real Fazenda." 35

Esta medida vinha sendo gestada desde 1796 quando um aviso régio solicitava ao vice-rei que informasse das medidas necessárias para a instauração de um governo independente no Rio Grande do Sul, mas concretizou-se de fato apenas em 1809, quando tomou posse oprimeiro governador e capitão-general, D. Diogo de Souza.

A condição de capitania subalterna limitava alguns poderes de seu governador e impedia, por exemplo, que ele concedesse cartas de sesmaria. Assim, até 1809, o pedido dessa mercê tinha de ser tramitado na cidade do Rio de Janeiro onde finalmente era concedida pelo Vice-rei. Uma larga distância geográfica e burocrática tinha de ser percorrida pelos pretendentes a esta graça, fator este que certamente incidiu nas primeiras décadas, em que as concessões de sesmaria foram bem escassas, como veremos adiante.

Uma observação se faz necessária antes de prosseguirmos. Ao estudar o ritmo de distribuição das sesmarias, de forma alguma estamos considerando que o processo de apropriação de terras resume-se a elas. A concessão de datas de terras pelos governadores, a ocupação pura e simples, as transações de compra e venda, as formas particulares de arrendamento e o uso da violência compõem o complexo processo de apropriação territorial e das formas que a produção agrária vai adquirindo. Apenas julgamos que a outorga de sesmarias pode ser um índice do acesso, ou não, à estrutura administrativa da Coroa, e um indicativo, um reflexo, do poder, econômico e social, de seus detentores, e de sua inserção bem sucedida em certas redes sociais.

Vejamos como isso ocorreu. Na década de 1730, apenas quatro sesmarias foram concedidas, na de 1740 foram nove e na década de 1750 saltaram para 42 . O que acontecia nestes anos? Assinado o Tratado de Madri, Gomes Freire deslocou-se para o sul para comandar a execução e a demarcação dos limites que as duas coroas pretendiam estabelecer. A presença de Gomes Freire in situ estimulou a solicitação de

\footnotetext{
35 Carta patente de 19 de setembro de 1807, Arquivo Histórico Rio Grande do Sul (doravante AHRS), Códice B. 2001. MIRANDA, Marcia Eckert, Continente de São Pedro: administração pública no período colonial, Porto Alegre, Assembléia Legislativa do Estado do RS, 2000, p.41.
} 
sesmarias. Várias delas foram concedidas e despachadas na localidade de Castilhos Grandes, em 1752, da mesma forma ocorrendo no ano de 1754 na região de Santo Amaro. Aqui confluíram o processo de reconhecimento e ocupação do território que a partida demarcadora realizou, e a possibilidade de acesso mais direto à autoridade que parece ter sido fundamental. Tanto assim que o número de cartas concedidas nesta década só foi ultrapassado na década de 1780, depois da retomada do porto de Rio Grande.

As décadas de 1760 e 1770 foram de refluxo das outorgas. A invasão da vila de Rio Grande em 1763, a perda significativa dos bens dos mais abastados moradores, o recuo dos habitantes para os campos de Viamão, a necessidade de estabelecer as centenas de casais açorianos aos quais ainda não havia sido concretizada a entrega de datas de terra, enfim, o estado de guerra produziu seus efeitos. Se a concessão de sesmarias caiu drasticamente, a criação de freguesias cresceu muito: seis na década de 1760 e mais sete na seguinte ${ }^{36}$.

Os gráficos 1 e 2 mostram-nos movimentos em sentido contrário: nas décadas com criação de muitas freguesias a concessão de sesmarias caiu drasticamente.

Esta conjuntura de guerra, que perdurou até 1777, mobilizou recursos, valorizou rebanhos e escravos em detrimento das terras, consumiu boiadas e cavalhadas e, ao mesmo tempo, forjou lideranças e poderes entre os oficiais das tropas de ordenanças e auxiliares e enriqueceu a muitos através do butim, essencialmente de animais, obtidos através destas incursões e razias nos chamados "campos indecisos". Estes oficiais afiançaram para si mais uma preciosa função: a de informadores dos pedidos de sesmaria. Com a existência de uma única Câmara distante dos vastos territórios, uma de suas atribuições, informar as peticões de sesmarias, foi transferida, de fato, pelos sucessivos governadores, aos oficiais de milícias das diferentes freguesias. Ao receber uma petição, ela era despachada pelo governador aos comandantes das freguesias para que informassem se os campos já estavam ocupados, ou povoados com gado, ou se havia outros pretendentes aos mesmos. A débil presença institucional da administração régia facultou-lhes esse

36 Os dados a seguir e sua respectiva análise já foram também apresentados em OSÓRIO, H. “Território, administração e expansão da fronteira meridional: o Rio Grande de São Pedro",Ismênia MARTINS e Márcia MOTTA (orgs.), 1808 - A corte no Brasil, Niterói, Editora da UFF, 2010, pp. 320327. 
poder de informação, que na verdade transformou-se em um poder arbitrário de escolha de quem ocuparia determinadas terras. Desta situação surgiram vários conflitos, que podem ser percebidos na documentação através, principalmente, de requerimentos e petições aos governadores por parte de prejudicados, que viviam o conflito quando o sesmeiro, com sua carta, aparecia reclamando as terras ${ }^{37}$.

Retornando aos gráficos, a distribuição de sesmarias nas décadasde 1780 e 1790 parecem acompanhar o crescimento econômico ocorrido. As 286 concessões da década de 1790 representam o dobro do número de sesmarias concedidas nas seis primeiras décadas.

Este pico de concessões deve refletir o processo de apossamento concreto ocorrido nas décadas anteriores e que foi formalizado com a concessão das cartas de sesmaria naquele momento. Novamente aqui um movimento inverso ao surgimento de freguesias:nenhuma foi erigida entre 1780 e 1809.

\section{Gráfico 1. Número de freguesias criadas na capitania do Rio Grande de São Pedro, por décadas, 1730-1800}

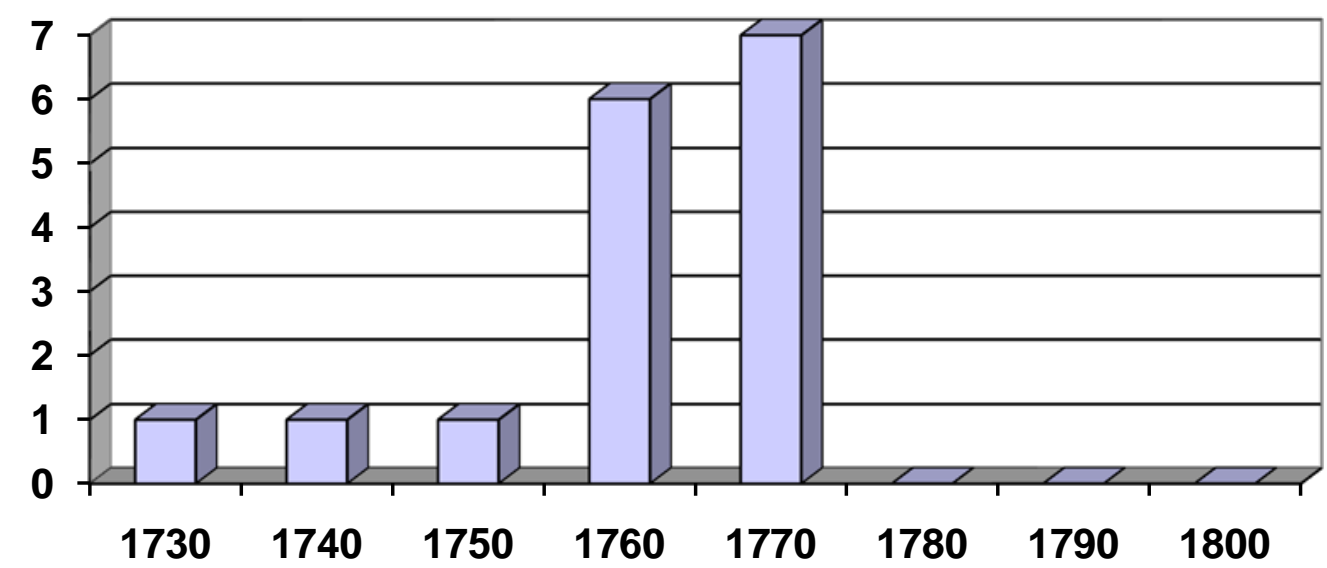

Fontes: AHU - cx. Rio Grande do Sul e Rio de J aneiro; Arquivo Histórico do Rio Grande do Sul (AHRS), Livros de Registro Geral e Arquivo Nacional, RJ .

37 OSÓRIO, Helen, Apropriação da terra no Rio Grande de São Pedro e a formação do espaço platino. Porto Alegre, Universidade Federal do Rio Grande do Sul, 1990. Dissertação de mestrado, 248 páginas. 


\section{Gráfico 2. Número de sesmarias distribuídas por décadas, Rio Grande de São Pedro, 1730-1809}

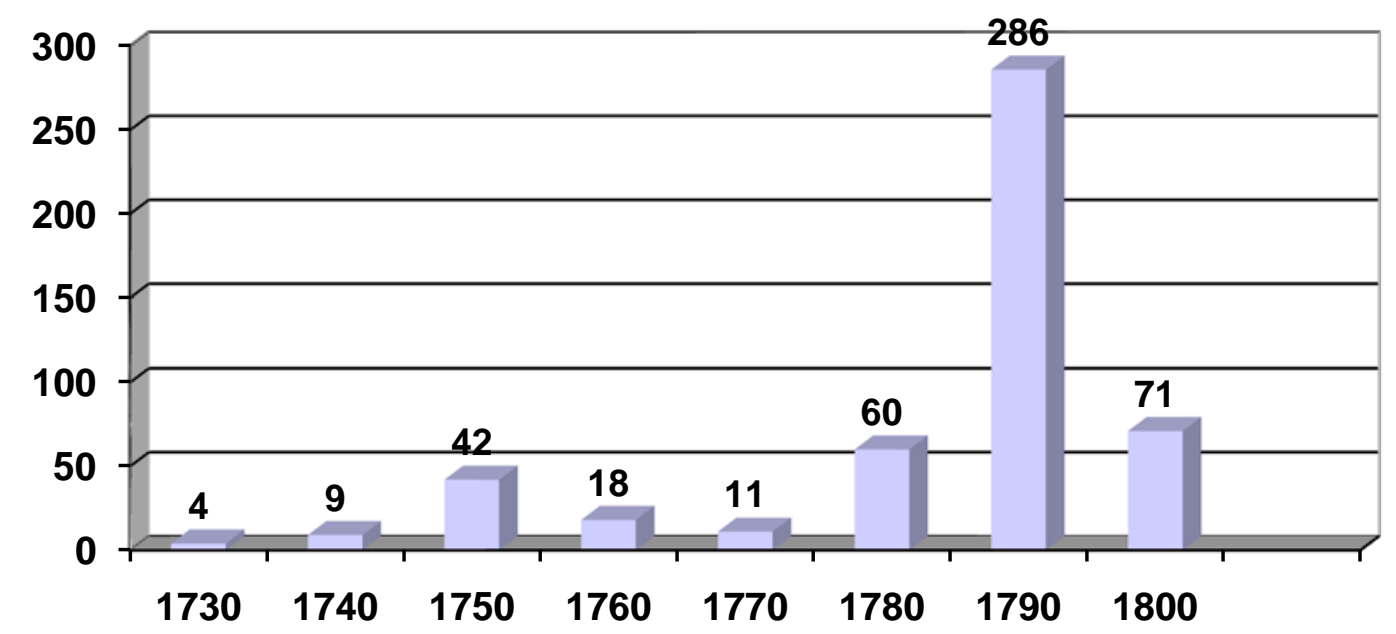

Fontes: AHU - cx. Rio Grande do Sul e Rio de Janeiro; Arquivo Histórico do Rio Grande do Sul (AHRS), Livros de Registro Geral e Arquivo Nacional, RJ .

\section{Administração e concessão de sesmarias no contexto pós 1808}

Depois do aluvião de concessões dos anos 1790, na primeira década do século XIX houve apenas modestas 71 concessões. Nos primeiros anos da década de 1810 o panorama é o mesmo. Mas, entre 1814 e 1816, há uma impressionante distribuição de 668 sesmarias, o que significou 30\% a mais de concessões donúmero havido entre 1738 e 1807. Que novidades administrativas e que dinâmicas sócio-econômicas ocorreram para que se verificasse esse "boom"?

Como já referimos, em 1809, o Rio Grande foi elevado à condição de capitania geral, tendo seu governador o poder de conceder sesmarias. No mesmo ano uma Provisão régia instituiria quatro vilas: Porto Alegre, Rio Grande, Rio Pardo e Santo Antônio. Em 1811 ocorreu o seu pleno estabelecimento, com sua instalação, eleição dos membros das câmaras e demarcação de seus termos ${ }^{38}$. Paralelamente, mais seis novas freguesias eram criadas, as primeiras desde a década de 1770. Três destas novas freguesias, Piratini (1810), Pelotas e Jaguarão conformaram o núcleo de produção de charque da capitania e expressavam a capacidade expansionista da colonização lusitana rumo a Banda Oriental. J aguarão, às margens do rio de mesmo

38 MIRANDA, ob. cit., p. 48. 
nome, originou-se a partir da guarda do Cerrito, que se situava nos limites dos territórios portugueses. Note-se que as duas últimas foram criadas em 1812, ano seguinte ao da primeira invasão portuguesa da Banda Oriental. Enfim, a malha eclesial e administrativa adensava-se nos territórios de recente incorporação ao império.

D. Diogo de Souza, que já fora capitão-general de Moçambique e do Maranhão, assume o governo em 1809 e no final de 1810 emite um Bando ${ }^{39}$ para regularizar a concessão de sesmarias e dirimir as disputas acerca de medições, sobras, e títulos precários. Já o Príncipe Regente, em 25 de janeiro de 1809 emitira um Alvará que no seu conjunto reiterava as disposições do Decreto de 1753 acerca da obrigatoriedade da medição das propriedades. Ele instituía, ainda, a obrigação de que em cada vila houvesse um juiz de sesmarias que serviria por três anos, bem como um piloto para as medições e demarcações eleito pela Câmara. A jurisdição do juízo de sesmarias, no entanto, não seria privativa, e poderia ser exercida pelos juízes de fora ou ordinários. As vilas da capitania acataram a diretiva e os juízos de sesmaria foram criados.

\section{Gráfico 3. Número de sesmarias concedidas por décadas, 1730-1820}

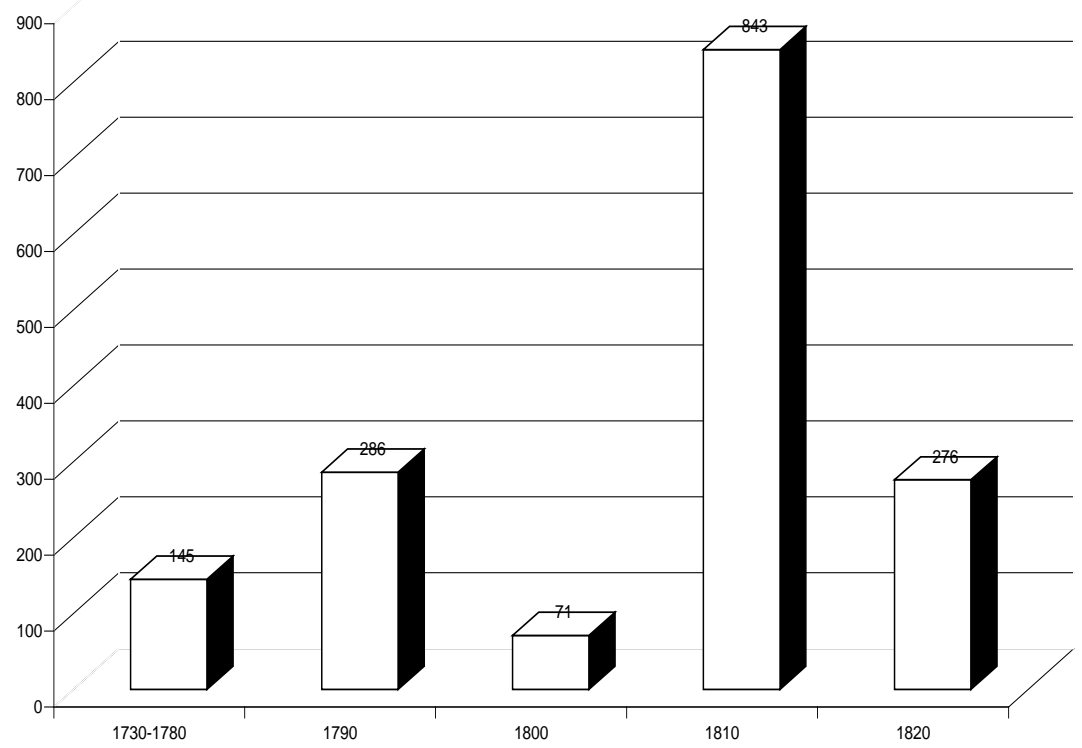

Fonte: AHU - cx. Rio Grande do Sul e Rio de Janeiro; Arquivo Histórico do Rio Grande do Sul (AHRS), Livros de Registro Geral e Arquivo Nacional, RJ .

39 Bando D. Diogo de Sousa de 29 de dezembro de 1810, transcrito em CHAVES, Antonio José Gonçalves, Memórias ecônomo políticas sobre a administração pública do Brasil. Quinta memoria [1823], Porto Alegre, Cia. Geral de Seguros, 1978. 
Apesar da proximidade da nova autoridade concedente das cartas, não se verificou um aumento do número de concessões entre 1810 e 1813. Apenas em 1814 há uma verdadeira enxurrada de títulos: foram outorgadas 306 cartas. Parece-nos que boa parte da explicação está na primeira invasão da Banda Oriental, perpetrada pelas tropas luso-rio-grandenses, em 1811. Em primeiro lugar, o governador D. Diogo de Souza comandou tropas e esteve ausente da capital por mais de um ano, entre julho de 1811 e setembro de 1812. As tropas lusas combateram grupos artiguistas em várias localidades e momentos, mas essencialmente percorreram o então denominado "distrito de Entre-Rios", um quadrilátero formado pelos rios Uruguai, Quaraí, Ibicuí e Santa Maria, vasto território naquele momento de posse indefinida e que atualmente faz parte do estado do Rio Grande do Sul ${ }^{40}$. Montaram aí um acampamento que originaria em 1816 uma capela e posteriormente o município de Alegrete, o mais extenso de toda a província. Também acamparam nas cabeceiras do rio Negro, nos cerros de Bagé, onde alguns anos depois surgiria a capela de Bagé, originando município com este nome. Na mesma região da campanha também foi formada capela em São Gabriel de Batoví, em 1815. Aí Azara havia fundado um povoado em 1801, rapidamente destruído pelos portugueses.

Ora, nada menos que 207 sesmarias das 296 concedidas, estavam situadas nesta imensa área, imprecisa região denominada de "fronteira do Rio Pardo", a qual, atualmente abarca a maior parte da fronteira com o Uruguai e parte da Fronteira com a Argentina. Se se observa as confrontações das terras apresentadas nas cartas, verifica-se uma grande quantidade que se definia apenas por acidentes geográficos, sem citar nenhum confinante, sinal de que se apropriava pela primeira vez tais terrenos. Os territórios conquistados em 1811-1812 foram, não sabemos em que proporção, apropriados sob a forma de sesmarias distribuídas provavelmente entre os militares das tropas de linha e auxiliares mais graduados, a partir de 1814. Por seus serviços militares de comandante da invasão, D. Diogo recebeu o título de Conde do Rio Pardo, e terminou se governo no final de 1814, ocupando posteriormente os cargos de Vice-rei da Índia (1816-1821) e presidente do Conselho Ultramarino (1825).

A segunda invasão da Banda Oriental ocorreu em 1816, por terra e mar. O domínio da capital Montevidéu e o avanço sobre a "campanha" foram afiançando a

40 Distrito de Entre-Rios, onde se situam atualmente os municípios de Uruguaiana, Quaraí, Santana do Livramento, Alegrete e parte de Rosário do Sul. 
investida dos criadores de gado rio-grandenses sobre os campos e rebanhos da Banda Oriental, o que resultou na expansão territorial portuguesa e na instituição de várias das grandes fortunas de estancieiros do século XIX.

Efetivamente, nos cinco anos entre 1814 e 1818, foram outorgadas 820 cartas de sesmaria, $70 \%$ a mais do que foram concedidas nos 70 anos que mediaram entre 1738 e 1808.

Saliente-se que as sesmarias continuaram sendo concedidas, mesmo após a independência do Brasil, até 20 de novembro de 1823. Apesar da resolução do príncipe regente de 17 de julho de 1822, que suspendia as doações ${ }^{41}$ ainda no ano de 1823 foram concedidas 75 cartas no Rio Grande do Sul.

Estas concessões consolidaram a conquista militar, ampliaram significativamente a fronteira, premiaram serviços e reatualizaram, enfim, as formas mais típicas da expansão da sociedade sulina e de sua classe de proprietários, que se estenderam pelo século XIX.

\section{A permanência das freguesias como referencial organizativo no contexto da organização do império do Brasil}

Concluiremos estas notas apontando a vigência que as freguesias mantiveram na organização territorial e política no Brasil independente, durante a primeira metade do século XIX. Para tal, tomaremos a primeira constituição do país, a de 1824, a lei de $1^{0}$ de outubro de 1828, que remodela a atribuição das Câmaras municipais e institui os juízes de paz, a lei de 18 de agosto de 1831, que cria as Guardas Nacionais e extingue os corpos de milícias e ordenanças e, por fim, o regulamento de 1854 da lei de Terras de 1850.42

Na constituição de 1824 o termo freguesia desaparece, sendo substituído por paróquia, mas não a sua função de circunscrição fundamental para o exercício político. É “a massa dos Cidadãos ativos” que, em assembléias paroquiais elegem os "eleitores de província", e estes os deputados, senadores e membros dos conselhos

41 VARELA, Laura Beck, Das sesmarias à propriedade moderna: um estudo de história do direito brasileiro, Rio de J aneiro, Renovar, 2005, p.110.

42 Disponíveis para consulta em: http:// bd.camara.leg.br/bd/handle/bdcamara/ 18299 
gerais das províncias (art. 90). A assembléia paroquial foi disciplinada pelo decreto de 26 de março de 1824. Em seu parágrafo segundo estipulava: "em cada freguesia deste império se fará uma assembléia eleitoral a qual será presidida pelo juiz de fora ou ordinário, ou quem suas vezes fizer, de cidade ou vila, a que a freguesia pertence, com assistência do pároco ou seu legítimo substituto". A eleição ocorreria após missa.

Também o processo para e eleição dos membros das Câmaras Municipais, disciplinada em 1828, dá-se todo no âmbito das paróquias. Onde não houvesse o juiz de paz, o pároco realizaria algumas de suas atribuições, como confeccionar a lista de eleitores da paróquia, que deveria ser afixada quinze dias antes da eleição, nas "portas da igreja matriz e das capelas filiais" (art. 5). A freguesia e seu pároco continuam, portanto, como elementos centrais das eleições. Avançando no tempo, a lei de 18 de agosto de 1831, que cria as Guardas Nacionais, também estabelece a circunscrição espacial das paróquias como ordenadora destes novos corpos.

Enfim, a Lei de Terras de 1850, instrumento jurídico fundamental para a modernização da propriedade territorial no rumo de sua absolutização, em seu regulamento de 1854, continua atribuindo fortes poderes à freguesia e seu pároco.Em seu art. 97 estabelece que "os vigários de cada uma das freguesias do Império são os encarregados de receber as declarações para o registro das terras, e os incumbidos de proceder a esse registro dentro de suas freguesias, fazendo - o por si ou por escrevente..." e, são os vigários que nas missas devem dar as instruções aos fregueses de como devem fazer tais declarações (art. 99). Portanto, segue na jurisdição eclesiástica o poder e competência para realizar os conhecidos "registros paroquiais de terras", único registro de tipo cadastro de terras abrangente realizado no império brasileiro.

Pode-se constatar, portanto, a permanência, centralidade e longa duração da organização espacial representada pelas freguesias, no ordenamento espacial e político do jovem estado brasileiro, até pelo menos a década de 1850. 


\section{Bibliografia}

BARRAL, María Elena,'Los párrocos como mediadores en las fronteras del mundo colonial (Buenos Aires rural en el siglo XVIII)", Darío BARRIERA, Justicias y Fronteras. El Río de la Plata (Siglos XVII a XIX),Murcia,Universidad de Murcia, 2009, pp. 65- 88.

BLUTEAU, Rafael, Vocabulario Portuguez e latino,Coimbra,Collegio das Artes da Companhia de J esu, 1712-1721. 8 v.

CANEDO, Mariana, "Derechos de propiedad, prácticas sociales e intervenciones políticas. Los pueblos rurales en Buenos Aires, 1750-1860". Ponencia presentada em el Congreso Internacional de historia agraria. Congreso internacional de la SEHA, Badajoz, 2013, 41 páginas.

CESAR, G., História do Rio Grande do Sul. Período colonial, Porto Alegre, Globo, 1970.

CHAVES, Antonio José Gonçalves, Memórias ecônomo políticas sobre a administração pública do Brasil. Quinta memoria [1823], Porto Alegre, Cia. Geral de Seguros, 1978.

COMISSOLI, Adriano,Os "homens bons" e a Câmara Municipal de Porto Alegre (1767-1808), Porto Alegre, Gráfica da UFRGS, 2008.

FONSECA, Cláudia Damasceno, Arraiais e vilas d'El Rei. Espaço e poder nas Minas setecentistas, Belo Horizonte, Editora UFMG, 2011.

FORTES, João Borges,Os casais açorianos. Porto Alegre, Martins Livreiro-editor, segunda edición1978,.

FRAGOSO, J oão L. R. y FLORENTINO, Manolo, O arcaísmo como projeto. Mercado atlântico, sociedade agrária e elite mercantil no Rio de J aneiro, c.1790-c.1840, Rio de J aneiro, Civilização Brasileira, $4^{a}$ edición, revista y ampliada, 2001.

FRAGOSO, João L. R., Homens de grossa aventura: acumulação e hierarquia na praça mercantil do Rio de Janeiro (1790-1830), Rio de Janeiro, Arquivo Nacional, 1992.

HESPANHA, A. M. e SILVA, Ana C. Nogueira da, "O quadro espacial", J. MATTOSO (dir.),História de Portugal. O Antigo Regime (1620-1807),Lisboa, Editorial Estampa, 1993,pp. 39-47.

MIRANDA, Marcia Eckert, Continente de São Pedro: administração pública no período colonial, Porto Alegre,Assembléia Legislativa do Estado do RS, 2000.

MORAES SILVA, Antonio de, Diccionario da lingua portugueza composto pelo padre D. Rafael Bluteau, reformado, e accrescentado por Antonio de Moraes Silva natural do Rio de J aneiro, Lisboa, Na Officina de Simão Thaddeo Ferreira, 1789.

MONTEIRO, Nuno Gonçalo, "Os poderes locais no Antigo Regime", César OLIVEIRA (dir.),História dos municípios e do poder local, Lisboa, Círculo de Leitores, 1996, pp. 17-175.

OSÓRIO, Helen, Apropriação da terra no Rio Grande de São Pedro e a formação do espaço platino, Porto Alegre, Universidade Federal do Rio Grande do Sul, 1990. Dissertação de mestrado, 248 páginas. 
O império português ao sul da América: estancieiros, lavradores e comerciantes, Porto Alegre, Editora da UFRGS,2007.

"Território, administração e expansão da fronteira meridional: o Rio Grande de São Pedro", Ismênia MARTINS e Márcia MOTTA (orgs.), 1808-A corte no Brasil, Niterói, Editora da UFF, 2010, pp. 317-330.

PORTO, Aurélio, História das Missões Orientais do Uruguai, Porto Alegre,Selbach, 1954,vol. 2.

RUBERT, Arlindo, História da Igreja no Rio Grande do Sul - Época Colonial (16261822), Porto Alegre, EDIPUCRS, 1994.

SAINT-HILAIRE, Auguste de, Viagem ao Rio Grande do Sul, Porto Alegre, Martins Livreiro Editor, segunda edición, 1987.

SANTOS, C. M., Economia e sociedade do Rio Grande do Sul, século XVIII, São Paulo, Editora Nacional, 1984.

VARELA, Laura Beck, Das sesmarias à propriedade moderna: um estudo de história do direito brasileiro, Rio de J aneiro, Renovar, 2005. 